\title{
Pengaruh Bahan Ajar Berbasis Self-Efficacy pada Pembelajaran Statistika SMP terhadap Kecemasan Matematika Siswa
}

\author{
Ahmad Dzulfikar
}

Institut Agama Islam Negeri Pekalongan, Indonesia

Correspondence: $\$ ahmad.dzulfikar@iainpekalongan.ac.id

\begin{tabular}{|c|c|}
\hline Article Info & Abstract \\
\hline $\begin{array}{l}\text { Article History } \\
\text { Received : 04-12-2018 } \\
\text { Revised : 28-04-2019 }\end{array}$ & $\begin{array}{l}\text { Students` self-efficacy in learning mathematics and its resources, such as students` } \\
\text { positive emotional conditions, have been impactful to create a pleasant } \\
\text { mathematical learning and the reduction of students mathematics anxiety. This }\end{array}$ \\
\hline Accepted : 07-05-2019 & study investigated the differences between students` mathematics anxiety before \\
\hline $\begin{array}{l}\text { Keywords: } \\
\text { Self-efficacy; } \\
\text { Mathematics anxiety; } \\
\text { Statistics; } \\
\text { Summative response scale }\end{array}$ & $\begin{array}{l}\text { and after the implementation of mathematics teaching materials based on self- } \\
\text { efficacy in statistical learning in mathematics classroom. This study was an } \\
\text { experimental study with One Group Pretest-posttest Design. The population of } \\
\text { the study was all eight grade students in one of the junior high schools in } \\
\text { Pekalongan in the } 2017 / 2018 \text { academic year. The sample of the study involved } 28 \\
\text { students taken by cluster sampling technique. After analyzing the data, this study } \\
\text { found that mathematics teaching materials based on self-efficacy effectively helped } \\
\text { reduce students 'mathematics anxiety, either when they learn in math class or when } \\
\text { they face math tests, or both. Even so, the level of students anxiety when they } \\
\text { face the math test was at a moderate level, both before and after the treatment, i.e. } \\
\text { the implementation of mathematics teaching materials based on self-efficacy in the } \\
\text { learning. Therefore, further research about the effect of this teaching materials on } \\
\text { students mathematics anxiety when facing tests is still needed }\end{array}$ \\
\hline
\end{tabular}

\section{PENDAHULUAN}

Salah satu sumber penggali self-efficacy adalah kondisi fisiologis dan emosi. Kondisi emosi siswa yang positif akan berkontribusi positif terhadap terhadap self-efficacy dan perfoma siswa dalam matematika. Dengan memperhatikan self-efficacy dalam pembelajaran dan sumber-sumber penggali seperti kondisi emosi positif siswa akan berdampak terciptanya pembelajaran matematika yang menyenangkan dan tereduksinya kecemasan matematika. Hal ini sejalan dengan temuan Pajares bahwa terdapat korelasi negatif antara self-efficacy dengan kecemasan dalam pemecahan masalah matematika [1]. Hal tersebut sejalan dengan temuan Jain \& Dowson yang menyebutkan bahwa meningkatnya self-efficacy seseorang akan dibarengi dengan berkurangnya kecemasan matematika pada dirinya [2].

Kecemasan matematika adalah perasaan tidak nyaman pada diri seseorang yang muncul ketika menghadapi permasalahan matematika atau situasi terkait dengan matematika [3]. Penelitian-penelitian sebelumnya menemukan bahwa kecemasan matematika memiliki pengaruh negatif terhadap prestasi matematika siswa $[4,5,6,7,8,9,10,11]$. Lebih lanjut, Gleason menjelaskan penyebab hal tersebut karena kecemasan matematika menyebabkan siswa menjadi sulit belajar dan mengaplikasikan konsep matematika [12].

Dalam penelitiannya, Dzulfikar menemukan kecemasan matematika siswa pada jenjang sekolah menengah pertama berada pada level sedang [13]. Sementara itu, Khatoon \& Mahmood menyatakan kecemasan matematika ditemukan pada siswa sekolah dasar, sekolah menengah, hingga mahasiswa pada jenjang perguruan tinggi [7] . Lebih lanjut, kecemasan matematika akan meningkat sejalan meningkatnya 
kompleksitas materi yang dipelajari yang berbanding searah dengan jenjang pendidikan. Berdasarkan uraian-uraian tersebut, kecemasan matematika pada diri siswa perlu direduksi sejak dini.

Memperhatikan penting dan pengaruhnya bagi siswa, peneliti memandang perlu untuk mengembangkan self-efficacy dalam pembelajaran matematika sekolah melalui infiltrasi self-efficacy dalam bahan ajar matematika. Hal ini dikarenakan beberapa penelitian sebelumnya merekomendasikan bahwa untuk mengoptimalkan pembelajaran dan kemampuan siswa dalam matematika selain dengan implementasi pembelajaran inovatif, juga dilakukan dengan perbaikan bahan ajar [14, 15, 16, 17].

Dalam penelitian ini diuji pengaruh bahan ajar matematika berbasis self-efficacy terhadap kecemasan matematika siswa. Bahan ajar matematika berbasis self-efficacy adalah bahan ajar yang dikembangkan dengan memperhatikan sumber-sumber penggali self-efficacy. Sumber-sumber tersebut adalah pengalaman keberhasilan, pengalaman orang lain, persuasi positif, serta kondisi psikologis dan emosi [18, 19]. Bahan ajar ini digunakan setelah melalui proses uji dan dinyatakan valid dan praktis oleh ahli dan praktisi. Selain itu, dalam pengembangannya bahan ajar ini mengacu pada salah satu pembelajaran yang diamanatkan pada kurikulum 2013, yaitu pembelajaran berbasis masalah atau Problem Based Learning. Oleh karena itu, siswa dalam belajar matematika dapat berkembang self-efficacy-nya. Selain itu, dengan memperhatikan bahan ajar tersebut, guru dapat menciptakan pembelajaran yang mampu mengembangkan self-efficacy siswa. Dengan berkembangnya self-efficacy siswa, diharapkan juga akan tercipta pembelajaran matematika yang menyenangkan dan kecemasan matematika siswa dapat berkurang. Muara yang diharapkan adalah meningkatnya prestasi matematika siswa.

\section{METODE PENELITIAN}

Penelitian ini dilaksanakan dengan menguji perbedaan kecemasan matematika siswa sebelum dan sesudah implementasi bahan ajar matematika berbasis self-efficacy pada pembelajaran matematika pada materi statistika. Penelitian ini merupakan penelitian eksperimen dengan desain One Group Pretest-Posttest. Populasi dalam penelitian ini adalah seluruh siswa kelas VIII di salah satu SMP di Kabupaten Pekalongan. Sampel dalam penelitian ini adalah 28 siswa, yang dipilih dengan teknik cluster sampling. Instrumen yang digunakan dalam penelitian ini dikembangkan dengan mengadaptasi indikator yang dikembangkan Cooke, et al. [20]. Instrumen digunakan setelah dinyatakan valid oleh ahli, dan dinyatakan valid dan reliabel berdasarkan uji empiris.

\section{HASIL DAN PEMBAHASAN}

Kecemasan matematika siswa dalam penelitian ini dikatakan tereduksi atau berkurang apabila secara statistik kecemasan matematika siswa setelah perlakuan lebih rendah dibanding kecemasan matematika sebelumnya. Lebih lanjut, dalam penelitian ini kecemasan matematika tersebut dianalisis berdasarkan kecemasan matematika ketika siswa belajar di kelas matematika, kecemasan matematika ketika siswa tes matematika, dan gabungan di antara keduanya. Untuk mengategorikan level kecemasan matematika siswa, digunakan adaptasi dari kriteria yang dikembangkan oleh Azwar [21].

Untuk menganalisis perbedaan rata-rata kecemasan matematika sebelum dan setelah perlakuan digunakan uji Wilcoxon. Uji ini digunakan karena data kecemasan matematika merupakan data yang berskala summative response scale yang berada di antara skala ordinal dan interval [22]. Oleh karena memiliki karakteristik di antara keduanya, maka pengujian statistik inferensial yang dapat digunakan adalah statistik non parametrik, dalam hal ini adalah uji Wilcoxon. Dalam penelitian ini, pengujian statistik menggunakan bantuan SPSS versi 22. 


\section{Kecemasan Matematika Ketika Siswa Belajar di Kelas Matematika}

Kecemasan matematika siswa ketika belajar di kelas matematika diidentifikasi dengan skala yang diberikan kepada siswa sebelum dan sesudah diberikan perlakuan berupa implementasi pembelajaran matematika dengan bahan ajar berbasis self-efficacy. Berikut ini disajikan statistik deskriptif kecemasan matematika ketika siswa belajar di kelas matematika.

Tabel 1. Statistik Deskriptif Kecemasan Matematika Ketika Siswa Belajar di Kelas Matematika

\begin{tabular}{lcccc}
\hline Kecemasan Belajar Matematika & $\mathrm{n}$ & Rata-rata & Interpretasi & Simpangan Baku \\
\hline Sebelum Perlakuan & 28 & 22,07 & Sedang & 4,59 \\
Setelah Perlakuan & 28 & 18,89 & Rendah & 3,52 \\
\hline
\end{tabular}

Skor tertinggi $=48$.

Tabel 1 tersebut menunjukkan bahwa terdapat penurunan kecemasan matematika siswa sebesar 3,18 setelah dilakukan implementasi bahan ajar berbasis selfefficacy. Kecemasan matematika siswa ketika belajar di kelas matematika sebelum perlakuan tergolong sedang, sementara setelah perlakuan kecemasan matematika siswa tergolong rendah. Lebih lanjut, berdasarkan data simpangan baku, skor kecemasan matematika siswa ketika belajar sebelum perlakuan cenderung lebih menyebar dibanding setelah perlakuan. Untuk mengkaji lebih lanjut apakah penurunan kecemasan tersebut signifikan, dilakukan pengujian, yang hasilnya disajikan pada Tabel 2 berikut.

Tabel 2. Hasil Uji Perbedaan Rata-rata Kecemasan Matematika Ketika Belajar di Kelas Matematika, Sebelum dan Sesudah Perlakuan

\begin{tabular}{cccc}
\hline z & Sig. $(1$-tailed $)$ & $\boldsymbol{\alpha}$ & Simpulan \\
\hline$-3,356$ & 0,0005 & 0,05 & Berkurang Signifikan \\
\hline
\end{tabular}

Berdasarkan data pada Tabel 2 tersebut diperoleh informasi bahwa perbedaan rata-rata kecemasan belajar matematika sebelum dan setelah perlakuan signifikan. Hal tersebut berimplikasi bahwa kecemasan matematika siswa ketika belajar di kelas matematika dengan bahan ajar berbasis self-efficacy lebih rendah secara signifikan dibanding sebelum diberikan perlakuan.

\section{Kecemasan Matematika Ketika Siswa Tes Matematika}

Aspek selanjutnya yang dikaji pada kecemasan matematika adalah kecemasan matematika ketika siswa menghadapi tes matematika. Pada penelitian ini dikaji adakah perbedaan kecemasan matematika sebelum dan sesudah diberikan perlakuan berupa implementasi bahan ajar matematika berbasis self-efficacy.

Tabel 3. Statistik Deskriptif Kecemasan Matematika Ketika Siswa Tes Matematika, Sebelum dan Setelah Perlakuan

\begin{tabular}{lcccc}
\hline \multicolumn{1}{c}{ Kecemasan Belajar Matematika } & $\mathrm{n}$ & Rata-rata & Interpretasi & Simpangan Baku \\
\hline Sebelum Perlakuan & 28 & 29,68 & Sedang & 4,96 \\
Setelah Perlakuan & 28 & 24,21 & Sedang & 4,98 \\
\hline
\end{tabular}

Skor tertinggi $=56$.

Data pada Tabel 3 menunjukkan bahwa meskipun kecemasan matematika siswa sebelum dan sesudah diberikan perlakuan berada pada level sedang. Akan tetapi, kecemasan matematika siswa ketika tes matematika setelah dilakukan penerapan pembelajaran dengan bahan ajar berbasis selfefficacy lebih rendah dibanding sebelum diterapkan perlakuan, dengan besar penurunan hampir mencapai seperlima dari skor kecemasan awal siswa ketika menghadapi tes matematika. 
Untuk mengkaji lebih lanjut signifikansi perbedaan tersebut, dilakukan uji perbedaan rata-rata sampel independen dengan uji Wilcoxon. Hasil uji tersebut disajikan pada Tabel 4 berikut.

Tabel 4. Hasil Uji Perbedaan Rata-rata Kecemasan Matematika Ketika Tes Matematika, Sebelum dan Sesudah Perlakuan

\begin{tabular}{cccc}
\hline $\mathrm{z}$ & Sig. $(1-$ tailed $)$ & $\boldsymbol{\alpha}$ & Simpulan \\
\hline$-4,070$ & 0,000 & 0,05 & Berkurang Signifikan \\
\hline
\end{tabular}

Berdasarkan hasil uji Wilcoxon sebagaimana ditunjukkan pada Tabel 4 tersebut, dapat disimpulkan bahwa terjadi penurunan signifikan kecemasan matematika ketika siswa tes matematika.

\section{Kecemasan Matematika Siswa}

Pada bagian ini disajikan hasil analisis data kecemasan matematika keseluruhan, baik ketika siswa belajar di kelas matematika ataupun ketika menghadapi tes matematika. Berikut ini disajikan statistik deskriptif data tersebut.

Tabel 5. Statistik Deskriptif Kecemasan Matematika Siswa, Sebelum dan Setelah Perlakuan

\begin{tabular}{lcccc}
\hline Kecemasan Matematika & $\mathrm{n}$ & Rata-rata & Interpretasi & Simpangan Baku \\
\hline Sebelum Perlakuan & 28 & 51,75 & Sedang & 8,85 \\
Setelah Perlakuan & 28 & 43,11 & Rendah & 7,40 \\
\hline
\end{tabular}

Skor tertinggi $=104$.

Data pada Tabel 5 menunjukkan kecemasan matematika siswa secara keseluruhan setelah dilakukan implementasi pembelajaran dengan bahan ajar matematika berbasis self-efficacy lebih rendah dibandingkan sebelum diberikan perlakuan. Berkurangnya kecemasan matematika siswa tersebut dapat dilihat dengan adanya penurunan kecemasan matematika siswa setelah implementasi pembelajaran dengan bahan ajar berbasis self-efficacy sebesar 16,7\% dibanding sebelum diberikan perlakuan tersebut. Lebih lanjut, kecemasan matematika siswa sebelum perlakuan tergolong dalam kategori sedang, sementara kecemasan matematika siswa setelah diimplementasikan pembelajaran dengan bahan ajar berbasis self-efficacy tergolong dalam kategori rendah.

Untuk mengkaji lebih mendalam efektivitas bahan ajar matematika berbasis self-efficacy dalam mereduksi kecemasan matematika dilakukan pengujian statistik yang hasilnya disajikan pada Tabel 6 berikut.

Tabel 6. Hasil Uji Perbedaan Rata-rata Kecemasan Matematika, Sebelum dan Sesudah Perlakuan

\begin{tabular}{cccc}
\hline $\mathrm{z}$ & Sig. $(1$-tailed $)$ & $\boldsymbol{\alpha}$ & Simpulan \\
\hline$-4,047$ & 0,000 & 0,05 & Berkurang Signifikan \\
\hline
\end{tabular}

Tabel 6 menyajikan data hasil pengujian statistik yang menunjukkan adanya penurunan secara nyata kecemasan matematika siswa sebelum dan sesudah diberikan perlakuan berupa penerapan pembelajaran dengan menggunakan bahan ajar berbasis self-efficacy.

Temuan penelitian ini menyajikan informasi bahwa bahan ajar berbasis self-efficacy efektif mereduksi kecemasan matematika. Berkurangnya kecemasan matematika terjadi baik pada kecemasan matematika ketika siswa belajar di kelas matematika, kecemasan matematika ketika siswa tes matematika, maupun keduanya. Lebih lanjut, selain berkurang secara signifikan setelah penerapan 
pembelajaran dengan bahan ajar berbasis self-efficacy, pada kecemasan matematika ketika siswa belajar di kelas matematika dan keseluruhan, terjadi penurunan level kecemasan dari sedang menjadi rendah.

Penurunan kecemasan matematika siswa tersebut terkait dengan pengembangan self-efficacy yang diinfiltrasikan pada bahan ajar. Bahan ajar statistika yang dikembangkan memperhatikan sumber-sumber self-efficacy. Sumber-sumber tersebut adalah pengalaman keberhasilan, pengalaman orang lain, persuasi positif, serta kondisi psikologis dan emosi $[18,19,1]$.

Siswa memperoleh pengalaman keberhasilan dalam pembelajaran yang menjadi sumber utama penggali self-efficacy melalui penyajian masalah pada bahan ajar yang disajikan menarik dan dekat dengan pengalaman siswa. Secara mandiri siswa berusaha dan memperoleh pengalaman berhasil dalam menyelesaikan masalah-masalah yang disajikan. Lebih lanjut, bahan ajar juga disajikan memperhatikan apersepsi dan prasyarat materi. Hal tersebut dilakukan agar siswa mengingat kembali konsep dasar yang dibutuhkan dan mengingat kembali pengalaman keberhasilan mereka ketika belajar materi sebelumnya.

Setelah siswa menyelesaikan masalah yang disajikan secara mandiri, melalui implementasi bahan ajar berbasis self-efficacy siswa diajak untuk berdiskusi dan membagikan hasil pemikirannya pada teman dalam kelompoknya. Dengan membagikan pengalaman penyelesaian masalah pada kelompoknya, siswa yang berhasil akan bertambah pengalaman keberhasilannya. Sementara, siswa yang belum berhasil dalam menyelesaikan masalah dapat memperoleh pengalaman keberhasilan dari teman dalam kelompoknya. Walaupun tidak sebesar pengalaman keberhasilan diri sendiri, tetapi pengalaman keberhasilan orang lain juga turut meningkatkan motivasi dan self-efficacynya. Hal tersebut juga berdampak pada tereduksinya kecemasan matematika siswa. Hal tersebut didukung hasil penelitian Pajares dan Jain \& Dowson yang menemukan bahwa meningkatnya self-efficacy seseorang akan dibarengi dengan berkurangnya kecemasan matematika pada dirinya [3, 2].

Dalam pembelajaran dengan menggunakan bahan ajar berbasis self-efficacy, kondisi psikologis dan emosi siswa dapat berkembang dengan baik. Hal ini dikarenakan dalam pembelajaran dengan mengacu pada bahan ajar ini siswa diberi persuasi positif yang juga disajikan pada bahan ajar. Sebagai sumber self-efficacy, dengan memperhatikan dan memberikan persuasi positif serta kondisi psikologis atau emosi yang baik pada siswa, self-efficacy siswa dalam dalam pembelajaran juga akan meningkat. Selain itu, bahan ajar berbasis self-efficacy juga disajikan dengan konteks yang dekat dengan siswa, yaitu terkait Kabupaten Pekalongan, tempat siswa tinggal. Dengan konteks yang disajikan dekat dengan siswa, bahan ajar disajikan realistik bagi siswa sehingga siswa menjadi tertarik belajar dan menyelesaikan masalah-masalah yang disajikan.

Implikasi dari data dan uraian tersebut adalah bahan ajar matematika berbasis self-efficacy secara nyata mereduksi kecemasan matematika siswa yang mula-mula berada pada level sedang menjadi level rendah. Oleh karena itu, bahan ajar matematika berbasis self-efficacy efektif mereduksi kecemasan matematika siswa. Hasil penelitian ini melengkapi penelitian-penelitian sebelumnya yang menemukan bahwa dengan implementasi pembelajaran inovatif efektif meningkatkan kemampuan matematis, tetapi belum mencapai level tinggi dan belum mampu mereduksi kecemasan matematika siswa [23, 17, 15, 24] [25]. Akan tetapi, masih diperlukan penelitian dan kajian lebih lanjut tentang pengaruh bahan ajar ini terhadap kecemasan matematika siswa ketika menghadapi tes. Hal ini dikarenakan, meskipun kecemasan siswa ketika menghadapi tes berkurang signifikan setelah diberikan perlakuan, tetapi masih tetap berada pada level sedang. 


\section{SIMPULAN DAN SARAN}

Penelitian ini menghasilkan temuan bahwa bahan ajar matematika berbasis self-efficacy efektif mereduksi kecemasan matematika siswa, baik keseluruhan, maupun dari aspek kecemasan siswa ketika belajar di kelas matematika dan kecemasan siswa ketika menghadapi tes matematika. Akan tetapi, berdasarkan hasil penelitian, meskipun berkurang kecemasan siswa ketika menghadapi tes matematika berada pada level sedang baik sebelum dan sesudah pemberian perlakuan berupa implementasi bahan ajar matematika berbasis self-efficacy dalam pembelajaran. Oleh karena itu, diperlukan penelitian lanjutan tentang pengaruh bahan ajar ini terhadap kecemasan matematika siswa ketika menghadapi tes.

\section{DAFTAR PUSTAKA}

[1] A. Dzulfikar, D. Dasari and S. Dewanto, "Improving Students' Mathematical Self Efficacy through Cooperative Learning of The Group Investigation Type," in Proceeding the 3rd IPCoRE Internasional Postgraduate Colloquium of Research in Education, Bandung, 2016.

[2] S. Jain and M. Dowson, "Mathematics Anxiety as a Function of Multidimensional Self-Regulation and Self-Efficacy," Contemporary Educational Psychology, vol. 34, pp. 240-249, 2009.

[3] A. Dzulfikar, "Kecemasan Matematika pada Mahasiswa Calon Guru Matematika," JMPM: Jurnal Matematika dan Pendidikan Matematika, vol. 1, no. 1, pp. 74-84, 2016.

[4] A. Erdogan, S. Kesici and I. Sahin, "Prediction of High School Students' Mathematics Anxiety by Their Achievement Motivation and Social Comparison," Elementary Education Online, vol. 20, no. 2, pp. 646652, 2011.

[5] B. M. Galla and J. J. Wood, "Emotional Self-Efficacy Moderates Anxiety-Related Impairments in Math Performance in Elementary School-Age Youth," Personality and Individual Differences, vol. 52, pp. 118-122, 2012.

[6] A. Karimi and S. Venkatesan, "Mathematics Anxiety, Mathematics Performance and Academic Hardiness in High School Students," International Journal of Education and Science, vol. 1, no. 1, pp. 33-37, 2009.

[7] T. Khatoon and S. Mahmood, "Mathematics Anxiety among Scondary School Students in India and Its Relationship to Achievement in Mathematics," International Journal of Education and Science, vol. 16, no. 1, pp. $75-86,2010$.

[8] J. L. Meece, A. Wigfield and J. S. Eccles, "Predictors of Math Anxiety and Its Influence on Young Adolescents'Course Enrollment Intentions and Performance in Mathematics," Journal of Educational Psychology, vol. 82, no. 1, pp. 60-70, 1990.

[9] E. Novak and J. L. Tassel, "Studying Preservice Teacher Math Anxiety and Mathematics Performance in Geometry, Word, and Non-Word Problem Solving," Learning and Individual Differences, vol. 54, pp. 2029, 2017.

[10] B. F. Sherman and D. P. Wither, "Mathematics Anxiety and Mathematical Achievement," Mathematics Education Research Journal, vol. 15, no. 2, pp. 138-150, 2003.

[11] E. Zakaria and N. M. Nordin, "The Effect of Mathematics Anxiety on Matriculation Students as Related to Motivation and Achievement," Eurasia Journal of Mathematics, Science \& Technology Education, vol. 4, no. 1, pp. 27-30, 2008. 
[12] J. Gleason, "Relationship between Pre-Service Elementary Teachers' Mathematics Anxiety and Content Knowledge for Teaching," Journal of Mathematics Science and Mathematics Education, vol. 3, no. 1, pp. 39-47, 2008.

[13] A. Dzulfikar, "Kemampuan Pemecahan Masalah Matematis, Mathematics Self-Efficacy dan Anxiety dalam Cooperative Learnig Tipe Group Investigation," Tesis pada Sekolah Pascasarjana, Bandung, 2014.

[14] R. Maya and U. Sumarmo, "Mathematical Understanding and Proving Abilities: Experiment with Graduate Student by Using Modified Moore Learning Approach," International Journal on Mathematics Education, vol. 2, pp. 231-250, 2011.

[15] U. Sumarmo and I. Nitishani, "High Level Mathematical Thinking: Experiments with High School and Under Graduate Students Using Various Approaches and Strategies," International Journal of Science and Mathematics Teaching, vol. 58, pp. 9-22, 2010.

[16] U. Sumarmo, "Pendidikan Karakter serta Pengembangan Berpikir dan Disposisi Matematik dalam Pembelajaran Matematika," in Seminar Pendidikan Matematika, Nusa Tenggara Timur, 2012.

[17] U. Sumarmo, "Pembelajaran Matematika," in Rujukan Filsafat, Teori, dan Praktis Ilmu Pendidikan, e. a. R. Natawidjaja, N. S. Sukmadinata, R. Ibrahim and A. Djohar, Eds., 2007, pp. 677-708.

[18] A. Bandura, "Guide for Constructing Self-Efficacy Scales," [Online]. Available: http://www.ravansanji.ir/files/ravansanji-ir/21655425banduraguide2006.pdf. [Accessed 2 November 2012].

[19] A. Bandura, Self-Efficacy: The Exercise of Control, New York: W.H. Freeman and Company, 1997.

[20] A. Cooke, R. Cavanagh, C. Hurst and L. Sparrow, "Situasional Effect of Mathematics Anxiety in PreService Teacher Education," in 2011 AARE International Research in Education Conference, Melbourne, Australia, 2011.

[21] S. Azwar, Sikap Manusia: Teori dan Pengukurannya (Edisi ke 2), Yogyakarta: Pustaka Pelajar, 2012.

[22] G. Gamst, L. S. Meyers and A. J. Guarino, Analysis of Variance Design: a Conceptual and Computational Approach with SPSS and SAS, NY, USA: Cambridge University Press, 2008.

[23] A. Dzulfikar, "Mereduksi Kecemasan Matematika Siswa SMP melalui Implementasi Cooperative Learning Tipe Group Investigation," Mathline, vol. 1, no. 1, pp. 1-13, 2016.

[24] N. Yuliana, "Pengaruh Pendekatan Different Instruction (DI) terhadap Kemampuan Pemahaman, Penalaran, dan Kecemasan Matematika (Math Anxiety)," Tesis pada Univeirsitas Pendidikan Indonesia, Bandung, 2013.

E. F. Ningsih, "Proses Berfikir Mahasiswa dalam Pemecahan Masalah Aplikasi Integral Ditinjau dari Kecemasan Belajar Matematika (Math Anxiety)", Jurnal Iqra': Kajian Ilmu Pendidikan., vol. 1, no. 2, pp. 192-216, 2016. 
Numerical: Jurnal Matematika dan Pendidikan Matematika, Vol. 3 No. 1 Juni 2019, 1-8 Ahmad Dzulfikar

[Halaman ini sengaja dikosongkan] 